\title{
CONTENTS OF VOLUME 38
}

ANDONOWATI: A two-sided shooting method in computation of travelling combustion waves of a solid material

ANDONOWATI: See K. K. TAM

J. ASAVANANT and J.-M. VANDEN-BROECK: Nonlinear free-surface flows emerging from vessels and flows under a sluice gate

D. D. BAINOV and I. M. STAMOVA: Second method of Lyapunov and comparison principle for impulsive differential-difference equations

BELINDA BARNES and ROGER GRIMSHAW: Analytical and numerical studies of the Bonhoeffer van der Pol System

K. BALACHANDRAN and J. P. DAUER: Relative controllability of nonlinear neutral Volterra integrodifferential systems

R. K. BERA and A. CHAKRABARTI: The sputtering temperature of a cooling cylindrical rod without and with an insulated core in a two-fluid medium

S. R. BISHOP: See M. J. CLIFFORD

JOSÉ LUIZ BOLDRINI: See MARKO A. ROJAS-MEDAR

RICHARD J. BOUCHERIE: On the Quiasi-stationary distribution for queueing networks with defective routing

L. R. BRAGG: Propagation relations for solutions of some higher order Cauchy problems

X. CAI: See S. ZHOU

YULING CAO and H. I. FREEDMAN: Global attractivity in time-delayed predator-prey systems

CARSTEN CARSTENSEN and ERNST P. STEPHAN: Adaptive boundary-element methods for transmission

A. CHAKRABARTI: See R. K. BERA

A. CHAKRABARTI and SAHOO: Reflection of water waves by a nearly vertical porous wall

GRAEME A. CHANDLER: See LAWRENCE K. FORBES

M. ASLAM CHAUDHRY and S. M. ZUBAIR: On a connection between the generalized incomplete gamma functions and their extensions

M. ASLAM CHAUDHRY and S. M. ZUBAIR: On an extension of generalized incomplete Gamma functions with applications

J. CHENG: See P. G. HOWLETT

J. R. CRISTIE, K. GOPALSAMY and M. P. PANIZZA: Subharmonic orbits in an anharmonic oscillator

M. J. CLIFFORD and S. R. BISHOP: Locating oscillatory orbits of the parametrically-excited pendilum

J. P. DAUER: See K. BALACHANDRAN

M. A. B. DEAKIN: The Laplace transform of $\exp \left(e^{t}\right)$

A. S. DOSTOVALOVA and S. T. SIMAKOV: Formation of singularities in a stratified fluid in the presence of a critical level

M. EL-GABALI: Efficient multiple-term approximations for the generalized elliptic-type integrals 
LAWRENCE K. FORBES, GRAEME C. HOCKING and GRAEME A. CHANDLER: A note on withdrawal through a point sink in fluid of finite depth

H. I. FREEDMAN: See YULIN CAO

K. GOPALSAMY: See J. R. CHRISTIE

JOHN R. GRAEF, et al: Oscillatory and asymptotic behavior of solutions of nonlinear neutraltype differential equations

ROGER GRIMSHAW: See BELINDA BARNES

XIANGJIAN HE: Oscillations of Interconnected Systems with $C^{0}$ Nonlinearities

L. D. HIRD and P. F. SIEW: Small Reynolds number flow between eccentric rotating cylinders with a permeable sleeve

GRAEME C. HOCKING: See LAWRENCE K. FORBES

GRAEME C. HOCKING: See H. ZHANG

P. G. HOWLETT and J. CHENG: Optimal driving strategies for a train on a track with continuously varying gradient

L. S. JENNINGS, K. H. WONG and K. L. TEO: Optimal control computation to account for eccentric movement

ZHUHAN JIANG: Matrix spectral problem with multiple-order jumps and poles

LIU JIANYONG and LIU KE: Markov decision programming - the moment optimal problem for the first-passage model

LIU KE: See LIU JIANYONG

A. A. KOLYSHKIN and RÉMI VAILLANCOURT: Double conductor line above a twolayered cylinder with varying properties

ZBIGNIEW LEYK: A $C^{0}$-Collocation-like method for elliptic equations on rectangular regions

W. D. McKEE: Bragg resonances in a two-layer fluid

A. A. K. MAJUMDAR: Generalized multi-peg Tower of Hanoi problem

C. A. MARTINI: See A. M. RUSSELL

AGNES MICIANO: See JOHN R. GRAEF

S. K. MISHRA and R. N. MUKERJEE: On generalized convex multi-objective nonsmooth programming

R. N. MUKERJEE: See S. K. MISHRA

DAVID MUSTARD: The fractional Fourier transform and the Wigner distribution

M. P. PANIZZA: See J. R. CHRISTIE

JOSIP PEČARIĆ: See SANJA VAROŠANEC

A. B. PLEASANTS, G. C. WAKE and A. L. RAE: The allometric hypothesis when the size variable is uncertain: issues in the study of carcass composition by serial slaughter

A. L. RAE: See A. B. PLEASANTS

J. A. RICKARD: See A. M. RUSSELL

A. J. ROBERTS: See S. D. WATT

MARKO A. ROJAS-MEDAR and JOSÉ LUIZ BOLDRINI: Global strong solutions of equations of magnetohydrodynamic type

A. M. RUSSELL, C. A. MARTINI and J. A. RICKARD: Welfare optimization and multinational monopolies 
SAHOO: See A. CHAKRABARTI

HUYUN SHA and J.-M. VANDEN-BROECK: Internal solitary waves with stratification in density

DONGHO SHIN and JOHN C. STRIKWERDA: Fast solvers for finite difference approximations for the Stokes and Navier-Stokes equations

P. F. SIEW: See L. D. HIRD

S. S. SIMAKOV: See A. S. DOSTOVALOVA

PAUL W. SPIKES: See JOHN R. GRAEF

I. M. STAMOVA: See D. D. BAINOV

ERNST P. STEPHAN: See CARSTEN CARSTENSEN

D. E. STEWART: A numerical method for friction problems with multiple contacts

288

JOHN C. STRIKWERDA: See DONGHO SHIN

P. SUNDARAM: See JOHN R. GRAEF

K. K. TAM and ANDONOWATI: Numerical study of a problem in the combustion of a porous medium

K. L. TEO: See L. S. JENNINGS

E. THANDAPANI: See JOHN R. GRAEF

PETER TRITSCHER: An integrable fourth-order nonlinear evolution equation applied to surface redistribution due to capillarity

H. D. TUAN: On solution sets of nonconvex Darboux problems and applications to optimal control with endpoint constraints

RÉMI VAILLANCOURT: See A. A. KOLYSHKIN

J.-M. VANDEN-BROECK: See J. ASAVANANT

J.-M. VANDEN-BROECK: See HUYUN SHA

SANJA VAROŠANEC and J. PEČARIĆ: Some integral inequalities, with application to bounds for moments of a distribution

G. C. WAKE: See A. B. PLEASANTS

S. D. WATT and A. J. ROBERTS: The construction of zonal models of dispersion in channels via matched centre manifolds

S. D. WATT: See R. O. WEBER

R. O. WEBER and S. D. WATT: Combustion waves

506

K. H. WONG: See L. S. JENNINGS

WENSHENG XU: A maximum principle for optimal control for a class of controlled systems

$X$. Q. YANG: A comparative study of smoothing approximations

CHIA-SHUN YIN and SONGPING ZHU: Selective withdrawal from stratified streams

H. ZHANG and G. C. HOCKING: Withdrawal of layered fluid through a line sink in a porous medium

S. ZHOU and X. CAI: Variance minimization - relationship between Completion-Time Variance and Waiting-Time Variance

SONGPING ZHU: See CHIA-SHUN YIN

S. M. ZUBAIR: See M. ASLAM CHAUDHRY 